\author{
SERIES "NONINVASIVE MONITORING OF AIRWAY INFLAMMATION" \\ Edited by H. Magnussen and F.E. Hargreave \\ Number 4 in this Series
}

\title{
Clinical aspects of exhaled nitric oxide
}

\author{
S.A. Kharitonov, P.J. Barnes
}

\begin{abstract}
Clinical aspects of exhaled nitric oxide. S.A. Kharitonov, P. J. Barnes. (C) ERS Journals Ltd 2000.

ABSTRACT: There has been intense research into the role nitric oxide (NO) plays in physiological and pathological mechanisms and its clinical significance in respiratory medicine.

Elevated levels of exhaled levels of exhaled NO in asthma and other inflammatory lung diseases lead to many studies examining NO as potential markers of airway inflammation, enabling repeated noninvasive and standardized monitoring of airway inflammation. In airway inflammation, NO is not merely a marker but may have antiinflammatory and pro-inflammatory effects. Significant correlation has been found between exhaled NO and skin test scores in steroid naive asthmatic patients, allowing to discriminate patients with and without airway responsiveness. Exhaled NO is significantly elevated in acute asthma, or steroid-resistant severe asthma, or when the maintenance dose of inhaled steroids is reduced, and quickly reduced down to the levels in patients with stable asthma after steroid treatment. Exhaled NO has been successfully used to monitor anti-inflammatory treatment with inhaled corticosteroids in asthma. Exhaled NO is extremely sensitive and rapid marker of the dose-dependent effect of steroid treatment, or asthma deterioration, which is increased to any changes in lung function, provocative concentration causing a $20 \%$ fall in forced expiratory volume, sputum eosinophilia or asthma symptoms. Exhaled NO is not increased in stable chronic obstructive pulmonary disease (COPD), but patients with unstable COPD, or bronchiectasis have high NO levels. Exhaled and nasal NO are diagnostically low in cystic fibrosis and primary pulmonary dyskinesia.

Analysis of exhaled air, including nitric oxide, is feasible and could provide a noninvasive method for use in monitoring and management of lung diseases.
\end{abstract} Eur Respir J 2000; 16: 781-792.

Dept of Thoracic Medicine, National
Heart and Lung Institute, Imperial
College School of Medicine, London, UK.

Correspondence: P.J. Barnes

Dept of Thoracic Medicine

National Heart and Lung Institute

Dovehouse St

London SW3 6LY

UK

Fax: 441713515675

Keywords: Asthma

exhaled breath

isoprostanes

nitric oxide

noninvasive markers of airway

inflammation

S-nitrosothiols

Received: May 232000

Accepted after revision May 252000
Accurate assessment of inflammation and oxidative stress in the lung is important in the clinical management of a variety of pulmonary conditions, including asthma, chronic obstructive pulmonary disease (COPD), cystic fibrosis and interstitial lung disease. It may allow the clinician to monitor the progression of the disease and to assess the efficacy of anti-inflammatory or antioxidant treatment. Traditional parameters including lung function, airway reactivity and symptoms are often difficult to interpret, as they may be affected by treatment with bronchodilators or corticosteroids.

Optimal and noninvasive monitoring of the effect of anti-inflammatory drugs in asthma is important, as asthmatic patients may require a life-long, individually tailored, treatment with corticosteroids. It has been suggested that it may take several weeks for inhaled corticosteroids to become effective. Recently, a variety of noninvasive approaches, such as exhaled breath analysis (exhaled gases and condensate) and induced sputum have been developed, which are changing the understanding about the speed of action of corticosteroids and their effect in asthma. However, sputum induction [1] cannot be used for day to day monitoring, as it provokes transient neutrophilia [2, 3], and the exhaled condensate approach is only in the early stage of development.

Exhaled nitric oxide (NO) has been validated against invasive measurements of inflammation by bronchoscopy $[4,5]$ and induced sputum in asthma [6-8], and it is not influenced by bronchodilators, such as albuterol or salmeterol [9-11]. The inflammatory origin [5, 12-15] of elevated levels of exhaled NO in asthma $[14,16]$, its responsiveness to suppression by corticosteroids $[17,18]$ and accumulating evidence of its association with asthma severity [19-21] make exhaled NO an effective and practical marker to monitor the effect of corticosteroid and other anti-inflammatory treatments in asthma. Exhaled NO may also be useful in the assessment of other inflammatory lung diseases.

Previous articles in this series: No 1: L. Jayaram, K. Parameswaran, M.R. Sears, F.E. Hargreave. Induced sputum cells counts: their usefulness in clinical practice. Eur Respir J 2000; 16: 150-159. No. 2: O. Holz, J. Kips, H. Magnussen. Update on sputum methodology. Eur Respir J 2000; 16: 335-359. No. 3: R.A. Jörres. Modelling the production of nitric oxide within the human airways. Eur Respir J 2000; 16: 555-560. 


\section{General principles of exhaled nitric oxide measurements}

Technical factors affecting exhaled nitric oxide measurements

Measurements of exhaled NO are usually made by chemiluminescence analysers and are based on the photochemical reaction between $\mathrm{NO}$ and ozone generated in the analyser. The specificity of exhaled NO measurements by chemiluminescence has been confirmed using gas chromatography-mass spectometry [22].

There are two main approaches to measurement of exhaled NO: on-line, during a single, flow-controlled exhalation against a resistance; off-line, using similar controlled exhalation during a single exhalation into reservoir. There are a few technical factors, which should be considered when exhaled NO measurements are used to monitor asthma treatment (table 1).

The European Respiratory Society (ERS) Guidelines on exhaled and nasal NO measurements was established in 1997 [23]. Recently, recommendations for standardized procedures for the on-line and off-line measurement of exhaled and nasal NO in adults and children has been published [24]. The standardization of techniques makes it possible to compare the results of clinical trials between different centres.

\section{Physiological, pathophysiological conditions and habits affecting exhaled nitric oxide measurements}

Conditions that may affect NO concentrations in exhaled air should be avoided, or registered and used for the interpretation of the data (table 2).

\section{Origin of nitric oxide in exhaled air}

The use of exhaled NO as a read out for airway inflammation depends on the understanding of its origin in exhaled air. Exhaled NO has a multiple cellular origins, as nitric oxide synthases (NOS) are expressed in several cell types in the respiratory tract, including epithelial and vascular endothelial cells, macrophages, eosinophils and neuons [25]. In fact, in most studies of normal subjects free of inflammation $[26,27]$, continuous NOS rather than inducible NOS is predominant in the airway wall [28].

Increased lower airway production of NO in asthma has been confirmed by direct sampling during bronchoscopy $[4,29]$, and in tracheotomized patients [30]. This has been indirectly supported by flow-dependence of exhaled NO and accumulation of NO during a breathhold [4, 31]. Patients with asthma, show increased levels of exhaled NO $[14,16]$ and related expression of inducible NOS (iNOS) and 3-nitrotyrosine [5] in bronchial epithelium.

Table 1. - Technical factors affecting exhaled nitric oxide (NO) measurements

\begin{tabular}{ll}
\hline Increased NO & Decreased NO \\
\hline $\begin{array}{l}\text { Low exhalation or sampling } \\
\text { flow rate }\end{array}$ & $\begin{array}{c}\text { High exhalation or sampling } \\
\text { flow rate } \\
\text { Breath holding } \\
\text { Spirometric manoeuvres } \\
\text { (transiently) }\end{array}$ \\
\hline
\end{tabular}

Table 2. - Physiological, pathophysiological conditions and habits affecting exhaled nitric oxide (NO) measurements

\begin{tabular}{|c|c|}
\hline Increased NO & Decreased NO \\
\hline \multicolumn{2}{|l|}{ Habits } \\
\hline Allergen and/or pollen exposure & Menstruation \\
\hline Air pollution & $\begin{array}{l}\text { Smoking } \\
\text { Acute alcohol ingestion }\end{array}$ \\
\hline Occupational exposure (ozone) & Mouth washing \\
\hline $\begin{array}{l}\text { Arginine ingestion, nitrite/ } \\
\text { nitrite-enriched food }\end{array}$ & \\
\hline \multicolumn{2}{|l|}{ Conditions } \\
\hline Asthma & $\begin{array}{l}\text { Nonasthmatic chronic } \\
\text { cough }\end{array}$ \\
\hline Unstable/severe COPD & Pulmonary hypertension \\
\hline Allergic rhinitis & Kartagener's syndrome \\
\hline URTI & Primary cillia diskynesia \\
\hline Influenza vaccination & Cystic fibrosis \\
\hline LPS administration & \\
\hline Bronchiectasis & \\
\hline Ulcerative colitis & \\
\hline Tuberculosis & \\
\hline Lung cancer & \\
\hline Active pulmonary sarcoidosis & \\
\hline
\end{tabular}

COPD: chronic obstructive pulmonary disease; URTI: upper respiratory tract infection; LPS: lipopolysaccharide.

Increased iNOS expression has also been reported in lung transplant recipients [32], and exhaled NO levels were dependent upon the intensity and extent of expression of iNOS in bronchial epithelium and BAL neutrophilia, but not in the subepithelial area in these stable lung transplant recipients free of infection, rejection, or obliterative bronchiolitis.

The profound effect of nebulized [33-35] versus the modest effect of comparable intravenous dose [36] of NOS inhibitors on exhaled NO also implicates that respiratory epithelium, but not vascular endothelial cells, as the major source of NO in exhaled air. This may also explain its particular sensitivity to inhaled corticosteroid which act topically in the airways.

\section{Exhaled nitric oxide compared to other means of asthma monitoring}

\section{Symptoms, lung function, bronchial hyperreactivity}

There is accumulating evidence for a significant relationship between exhaled NO, clinical signs and symptoms of asthma, especially during acute exacerbations. However, longitudinal studies are needed to confirm that exhaled NO may be used not only for a short-term management, but to guide a long-term management and treatment of asthma of different severity.

The traditional means of asthma monitoring are not sensitive enough to demonstrate dose-dependent effect of inhaled steroids, especially in mild asthma. The fundamental limitation of the lung function and provocative concentration causing a $20 \%$ fall in forced expiratory volume in one second (FEV1) (PC20), a reflection of airway obstruction and airway hyperresponsiveness assessed by provoked airway obstruction, in monitoring of asthma is that they are not directly related to airway inflammation. In addition, FEV1 has a small room for improvement in mild asthma 
and $\mathrm{PC} 20$ is affected by corticosteroids and cannot be routinely performed in severe asthmatics. Both parameters are slow to change and lack a discriminating power to distinguish the effect of different doses of steroids.

For example, only moderate positive changes in FEV1 and $\mathrm{PC}_{20}$ were seen in mild asthma after 4 weeks of treatment with high $(1,600 \mu \mathrm{g})$ dose of budesonide, but these changes were not significantly different from the placebo group [37]. Indirect inhaled spasmogen, such as adenosine monophosphate (AMP), might be more specific and demonstrate dose-dependent changes in PC20 compared with placebo after moderate $\left(400 \mu \mathrm{g} \cdot \mathrm{day}^{-1}\right)$, or high $\left(1,600 \mu \mathrm{g} \cdot\right.$ day $\left.^{-1}\right)$, but not low $\left(100 \mu \mathrm{g} \cdot \mathrm{day}^{-1}\right)$ doses of inhaled steroids. In contrast, a significant reduction in exhaled NO, which was different from the placebo and coincided with improvement in asthma symptoms and lung function, was seen after $1,600 \mu \mathrm{g}$ and much lower doses of budesonide $100 \mu \mathrm{g}$ and $400 \mu \mathrm{g}$ [38]. The latter changes were also dose-dependently different.

The advantage of exhaled NO measurements is that the changes in NO during steroid treatment are dose-dependent and precede the improvement in symptoms, FEV1 [17] and sputum eosinophils [6] in asthma. Recently, it has been demonstrated that $400 \mu \mathrm{g}$ budesonide rapidly reduced NO and abolished night-time asthma symptoms in all patients within 3 days (12193). This was also associated with amelioration in FEV1. The onset of action of $100 \mu \mathrm{g}$ budesonide was slower and its effect on NO was less marked and this was reflected in a slower improvement in night-time symptoms.

This rapid increase of exhaled NO when steroid treatment is stopped precedes the reduction in lung function, with FEV1, or PC20 to return to the pretreatment level over 1 week [39]. Exhaled NO measurements may therefore serve as a fast responding indicator to assess patients compliance with therapy and to titrate their steroid treatment. For example, increasing levels of exhaled NO, asthma symptoms and use of $\beta_{2}$-agonists during the third week of treatment with low dose of budesonide, might be an indication of the loss of asthma control and the need to increase the dose of steroids. On the other hand the data gave further support to the fact that most patients with mild-to-moderate asthma may require low doses of steroids taken once daily to achieve or to maintain an adequate control [40].

The relationship between exhaled NO and FEV1 depends on the severity of asthma. There is no strong link between exhaled NO, FEV1 and symptoms in mild steroidnaive asthma measured under stable conditions $[14,16]$. However, higher concentrations of exhaled NO were linked to recent symptoms of bronchial obstruction [41], and NO was 2.6 times higher in children with recent symptoms compared with symptom-free subjects [41]. Exhaled NO correlated with symptom frequency and with rescue $\beta_{2}$-agonists use, and is significantly higher in those patients with difficult/severe asthma who have the highest symptom score where changes in lung function may have limited sensitivity [19].

\section{Induced sputum}

Elevated levels of exhaled NO have been validated against invasive measurements of inflammation by bron- choscopy [4, 5, 29] and induced sputum [6], and a significant correlation has been found between exhaled NO and iNOS positive granulocytes in sputum eosinophils [7, 8].

One of the most attractive features of exhaled NO measurements is that they can be repeated at short intervals without affecting endogenous NO production, or causing discomfort to the patients. This is invaluable to study an acute effect and onset of action of a variety of drugs, or tests that can influence NO production in patients of different severity and age.

Sputum induction, however, may cause a bronchoconstriction despite salbutamol pretreatment [8] and significant fall in arterial oxygen saturation $\left(\mathrm{Sa}_{\mathrm{a}} \mathrm{O}_{2}\right)$ [42] during the inhalation of hypertonic saline solution, as well as neutrophilia detectable for at least $24 \mathrm{~h} \mathrm{[2]} \mathrm{thereafter,} \mathrm{and}$ other changes in their cellular and biochemical composition, both in healthy subjects and mild asthmatic patients $[3,43]$.

Exhaled NO has a low threshold towards the effect of steroids and therefore, even a low dose of locally applied steroids are capable of a significant reduction in exhaled NO. The use of sputum eosinophils as read-out for steroid treatment efficacy might be limited. It has been shown that only high $\left(1,600 \mu \mathrm{g} \cdot \mathrm{day}^{-1}\right)$, or medium $\left(400 \mu \mathrm{g} \cdot\right.$ day $\left.^{-1}\right)$ [37, $44]$, but not low $\left(100 \mu \mathrm{g} \cdot \mathrm{day}^{-1}\right)$ doses $[38,44]$ of inhaled steroids were able significantly reduced the number of eosinophils in sputum. No dose-dependent changes were observed in sputum eosinophils after either low, moderate [38], or high [44] dose of inhaled steroids. Sputum eosinophils may not reflect the full extent of asthma severity, or the effect of inhaled steroids, as the cellular and biochemical composition of the larger airways (higher presence of eosinophils, neutrophils and eosinophil cationic protein (ECP)) is different from the peripheral airways (higher presence of macrophages, surfactant protein) and depends on the duration of sputum induction [45].

However, the combined use of exhaled NO measurements and sputum induction is of particular importance in severe persistent, or steroid-resistant asthma, which is associated with elevated, despite of massive steroid treatment, levels of exhaled NO [19, 46], neutrophilia [46] and oxidative stress. It has been shown that elevated ECP levels, but not eosinophil numbers in induced sputum of corticosteroid-dependent asthmatics with recent exacerbations may be a more accurate assessment of airway inflammation in these patients [47]. The correct identification of these patients by their profile of inflammatory cells and mediators in sputum is crucial, as they may require a different treatment.

\section{Use of exhaled nitric oxide to monitor asthma}

It has been shown that exhaled NO can be significantly reduced or even normalized whilst other markers of airway inflammation, e.g. number of eosinophils in sputum, is still high.

However, exhaled NO is the first marker to increase during asthma deterioration suggesting that it can be used as a loss of control marker in asthma [17]. Exhaled NO levels were increased prior to the significant changes in lung function, PC20, sputum eosinophilia or asthma symptoms. 
Elevation of exhaled NO has been seen in patients with severe persistent asthma, despite treatment with high dose inhaled and/or oral steroids [19], or in acute asthma, or when the maintenance dose of inhaled steroids is reduced [17]. During acute asthma exacerbations exhaled NO is a more sensitive marker of asthma activity than serum markers, such as ECP or soluble interleukin, and appears to be a more useful indicator of the beneficial response to glucocorticosteroid therapy in paediatric asthma [20].

Exhaled NO correlates with symptom frequency and with rescue $\beta_{2}$-agonists use, and is significantly higher in those patients with difficult/severe asthma who had the highest symptom score where changes in lung function may have limited sensitivity [19]. Furthermore, the identification of subjects in whom exhaled NO levels remain markedly increased in spite of high dose corticosteroid therapy may influence steroid or lead to use of a different type of therapy, for example iNOS inhibitors [33, 34], anti-oxidants, or leukotriene antagonists.

Diagnosing and screening for asthma, atopy, chronic cough

Although elevated exhaled NO levels are not pathognomic for asthma, NO measurements may be useful in asthma and atopy screening in patients referred from primary care, or to monitor reactivation of airway allergic inflammation in allergic asthmatic adults and children.

Exhaled NO is increased in asthma [14, 16, 19, 48] and in allergic/atopic adults and children [49-52]. Elevated levels of NO are strongly associated with conditions known to increase inflammation in asthma, such as allergen provocation challenge [53], pollen season [54], animal allergy [49], or indoor allergens in sensitized asthma patients [55]. Exhaled NO was significantly elevated in allergic rhinitis in the nonpollen season and increased further in the pollen season, indicating airway inflammation and an increased risk for developing asthma [56]. Increased levels of exhaled NO due to an acute, or chronic allergen exposure $[49,53]$ and can be prevented by the avoidance of allergens [57], or by treatment with corticosteroids [52].

Atopic asthmatics have much higher levels of exhaled NO $[49,50,58,59]$ than subjects with nonatopic asthma. Significant correlation has been found between elevated exhaled NO and skin test scores, total immunoglobulin $(\operatorname{Ig}) \mathrm{E}[60,61]$, and blood eosinophilia [62] in steroid naive asthmatic patients, and much higher levels, both for exhaled and nasal NO, have been found in atopic patients with rhinitis compared to nonatopic subjects [51, 58].

However, not all forms of airway inflammation are accompanied by increased levels of exhaled NO. Patients with chronic cough not attributable to asthma [63], or due to gastro-oesophageal reflux $[64,65]$ have low NO values compared with healthy volunteers and patients with asthma. Exhaled NO may therefore be a useful screening tool for patients with chronic cough.

\section{Effects of treatments on exhaled nitric oxide asthma}

\section{Oral corticosteroids}

The effect of steroids on exhaled NO depends on the degree of iNOS induction. Oral prednisolone $(30 \mathrm{mg}$ daily for 3 days) reduces elevated exhaled NO in asthmatic patients, whereas it has no effect on exhaled NO in normal subjects [33]. This is presumably because iNOS is the major source of increased exhaled NO in asthma, whereas the major source of exhaled NO in normal subjects is the constitutive NOS, which is not suppressed by corticosteroids. Prednisolone $\left(30 \mathrm{mg} \cdot \mathrm{day}^{-1}\right)$ produced a significant, but moderate $(22 \%)$ reduction in exhaled $\mathrm{NO}$ within $72 \mathrm{~h}$ in mild asthmatics [33]. A high dose of methylprednisolone $(180-500 \mathrm{mg})$ caused a $36 \%$ reduction within $50 \mathrm{~h}$ in the majority of exacerbation of asthma [66]. A high dose $\left(1 \mathrm{mg} \cdot \mathrm{kg}^{-1} \cdot \mathrm{day}^{-1}\right.$ for 5 days $)$ of oral prednisolone also normalized exhaled NO in infants and young children with wheezing exacerbations [67], whereas the same dose in more severe asthmatic children only shifted their exhaled NO down to the levels of mild-tomoderate asthma, in spite of the improvement in lung function [10].

\section{Inhaled corticosteroids}

Exhaled NO has been successfully used to monitor antiinflammatory treatment with inhaled corticosteroids in asthma $[14,18,37,68,69]$. Exhaled NO is a very sensitive and rapid marker of the effect of steroid treatment (table 3). A significant reduction in exhaled NO levels has been observed $6 \mathrm{~h}$ after a single high-dose $(8 \mathrm{mg})$ of nebulized budesonide in symptomatic moderate asthma [72]. Dose-dependent changes in NO have been reported during 3-week treatment with $100 / 400 \mu \mathrm{g}$ budesonide in mild asthma [38].

Recently, it has been shown that the onset of action of inhaled budesonide on exhaled NO and the time to reach the maximal reduction are dose-dependent. The higher dose of budesonide reduced NO and improved night-time asthma symptoms in all patients within 3 days and increased FEV1 [74]. The onset of action of $100 \mu \mathrm{g}$ budesonide was slower, its effect on NO was less marked and this was related to a slower improvement in nighttime symptoms. The difference between the effect of 100 $\mu \mathrm{g}$ versus $400 \mu \mathrm{g}$ BUD on NO was apparent within 3 days and was maximal after 5 and 21 days. NO was further reduced during the third week of treatment with $400 \mu \mathrm{g}$ BUD, in contrast to a minor NO increase in the $100 \mu \mathrm{g}$ BUD group, which coincided with the return of asthma symptoms and increased use of $\beta_{2}$-agonists.

The effect of inhaled corticosteroids may be via a direct inhibition of iNOS induction via inhibition of transcription factors activity [75], such as nuclear transcription factor (NF)- $\kappa \mathrm{B}$, or inflammatory cytokines, such as tumour necrosis factor(TNF)- $\alpha$, or interleukin(IL)-1 $\beta$, which induced iNOS, or by inhibition of recruitment of inflammatory cells, such as eosinophils, which express iNOS [76]. It has been shown that no longer than $24 \mathrm{~h}$ is needed for inhibition of iNOS activity (24 h) [75] and only $30 \mathrm{~min}$ for the NF- $\kappa$ B after application of corticosteroids [77].

An important issue that remains to be resolved is what level of exhaled NO needs to be achieved during the 
Table 3. - Effect of corticosteroids on exhaled nitric oxide (NO)

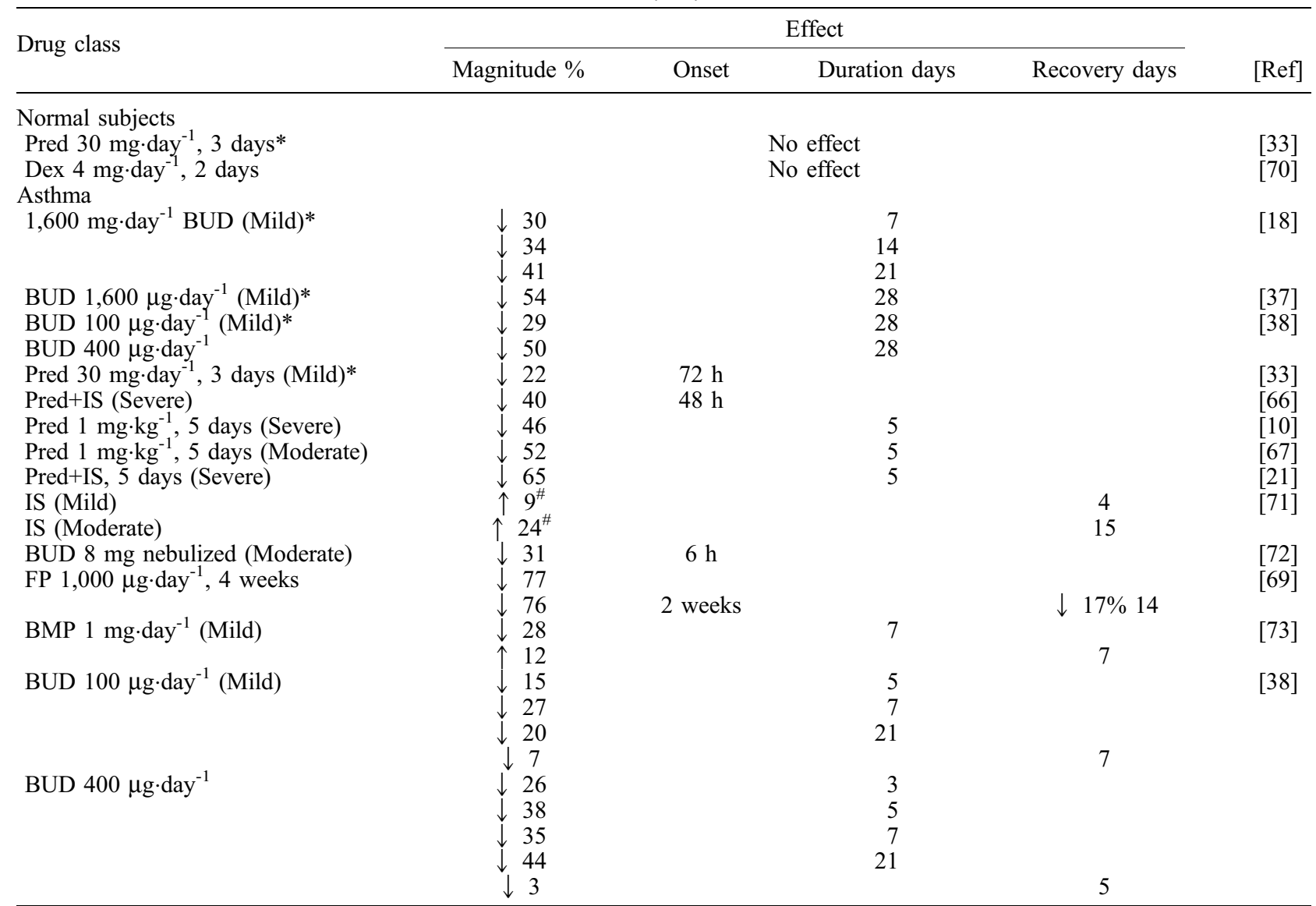

Pred: prednisolone; Dex: dexamethasone; BUD: budesonide; FR: fluticasone; FL: flunisolide; IS: inhaled steroids; $\downarrow:$ decrease; $\uparrow$ : increase; *: placebo-controlled randomized trial; Mild: mild asthma; Moderate: moderate asthma; Severe: severe asthma; ${ }^{\#}:$ values presented as parts per billion (volume by volume).

treatment. Exhaled NO levels in mild asthma are substantially reduced, but not normalized after a course of different doses $(100-1,600 \mu \mathrm{g})$ of inhaled steroids [33, 38, 69]. However, the larger dose $\left(1 \mathrm{mg} \cdot \mathrm{kg}^{-1} \cdot \mathrm{day}^{-1}\right.$ for 5 days $)$ of oral prednisolone normalized exhaled NO in infants and young children with wheezing exacerbations [67], while in more severe asthmatic children exhaled NO levels were reduced to the mild-to-moderate asthma range [10].

A high dose of inhaled fluticasone propionate (FP; 500 $\mu \mathrm{g}$ b.i.d.) reduced exhaled NO reduction by $76 \%$ after 2 weeks and $77 \%$ after 4 weeks of treatment [69]. Indeed, NO levels were not fully recovered ( $83 \%$ of the baseline) after 2 weeks after the end of treatment. However, a high dose of budesonide $\left(1,600 \mu \mathrm{g} \cdot \mathrm{day}^{-1}\right)$ reduced exhaled NO only by $48 \%$ after 3 weeks with a further reduction to $54 \%$ after four weeks of treatment $[18,37,38]$. The levels of $\mathrm{NO}$ were not fully recovered two weeks after FP was stopped, whilst NO levels in the study with budesonide [73] returned to the almost pretreatment values within 3-5 days regardless of the dose of budesonide.

\section{Inhaled $\beta_{2}$-agonists}

The short-acting $\beta_{2}$-agonist salbutamol (5 mg via nebulizer or $400 \mu \mathrm{g}$ by metered-dose inhaler) has no acute effect on exhaled NO $[9,10,77]$. Similarly, 1 week of treatment with a long-acting inhaled $\beta_{2}$-agonists, salmeterol, does not reduce NO in adults or children [9-11]. This is consistent with the fact that inhaled $\beta_{2}$-agonists do not have any effect on chronic inflammation in asthma and validates the use of exhaled NO to measure inflammation independently of airway calibre.

\section{Leukotriene antagonists}

A leukotriene synthase inhibitor (pranlukast) inhibits the rise in exhaled NO when the dose of inhaled corticosteroids is reduced [79]. Rapid reduction of exhaled NO has been recently reported after montelukast, leukotriene receptor antagonist, in children with asthma. The mechanism of this moderate $15 \%$ [ 80$]$, or $30 \%$ [81] reduction is not clear, but may reflect a weak effect on the inflammatory cytokines that induce iNOS in eosinophils.

Inducible nitric oxide synthase inhibitors, prostaglandins and other drugs

The use of NO modulators, for example iNOS inhibitors, or prostaglandins $(\mathrm{PG}) \mathrm{E}_{2}$, are presently at the stage 
of clinical research. Potentially, NO modulators may be important in management of severe asthma in which a combination of airway inflammation and oxidative stress together with an inherited, or acquired resistance to steroids makes their treatment difficult.

Endogenous NO may play an important role in the persistent airway inflammation and hyperresponsiveness and treatment with aminoguanidine, a relatively specific iNOS inhibitor may be beneficial. Both, aminoguanidine and $\mathrm{N}^{\mathrm{G}}$-nitro-L-arginine methyl ester (L-NAME) can be safely given and caused a significant reduction in exhaled NO in asthmatic patients $[33,34]$. More chronic treatment will be required to demonstrate whether NO contributes to the persistence of asthmatic inflammation in humans.

$\mathrm{PGE}_{2}$ and $\mathrm{PGF}_{2 \alpha}$ also decrease exhaled $\mathrm{NO}$ in normal and asthmatic subjects, irrespective of changes in airway calibre [82]. This effect occurs rapidly and is presumably due to an inhibitory effect of cyclooxygenase products on NOS directly rather than through altered gene transcription [83].

Despite of positive changes in $\mathrm{PC} 20$ in asthmatics treated with seratrodast, thromboxane (TX) $\mathrm{A}_{2}$ antagonist, there was no differences in either exhaled NO or sputum eosinophils [84]. The effects of theophylline and cromones on exhaled NO have not yet been reported.

\section{Exhaled nitric oxide in other lung diseases}

\section{Cystic fibrosis}

Exhaled NO measurements may have a diagnostic value in cystic fibrosis (CF). Remarkably low NO levels have been reported, with the exception of one paper [85], in exhaled [86-89] and nasal [90] air of patients with CF. There is also evidence of low NO production in the airways of CF mice through a loss of expression of the iNOS and this is related to diminished NO production in response to lipopolysaccharide, reduced bactericidal activity in the lungs [91, 92], and to dysfunction in epithelial ion transport [93].

It has been shown that the airways in patients with $\mathrm{CF}$ are exposed to increased oxidative stress, which appears to be a consequence of pulmonary inflammation rather than part of the primary CF defect $[94,95]$. Influx of airway neutrophils releasing superoxide, which converts NO to nitrate, may explain the lack of elevation of exhaled NO in CF [96, 97], and the lack of response of elevated sputum $\mathrm{NO}_{2} / \mathrm{NO}_{3}$ levels to antibiotic and corticosteroid treatment during acute pulmonary exacerbations [98]. Patients with CF are also more susceptible to oxidative cell injury than normal healthy children. This is due to both the impaired absorption of antioxidant nutrients and the increased oxidative stress [99] contributing to the decline in pulmonary function [100] and oxidative damage to deoxyribonucleic acid (DNA) [101] explaining, perhaps, a higher incidence of malignancy in CF patients. A dramatic reduction of iNOS expression in airway and nasal epithelium in patients with CF [91] may hinder an important first-line defence mechanism and increase the susceptibility of the airways to bacterial infections.

\section{Chronic obstructive pulmonary disease}

The usefulness of exhaled NO measurements in assessment of airway inflammation in COPD still needs to be established. Exhaled NO is not elevated in stable COPD [102-105] and NO sensitivity towards corticosteroids is of limited value, as they are, in general, ineffective in COPD.

The low NO levels in COPD may be due to several reasons including chronic cigarette smoking, and oxidative stress. Much lower exhaled [102, 106, 107] and nasal NO [108] levels were detected in smokers than in nonsmokers. This may be explained by partial irreversible inhibition of NOS by cigarette smoke extract [109, 110], or by conversion of NO to peroxynitrite release by neutrophils [96].

Low levels of exhaled NO do not imply that nitrosative stress plays a small role in COPD, as the formation peroxynitrite and, eventually 3 -nitrotyrosine in plasma in normal smokers [111], may be deleterious considering not only its involvement in cigarette smoke-induced inflammatory reactions, but also reported genotoxic effects [112].

Exhaled NO may have a role in identification of patients with severe, unstable COPD who have elevated NO levels compared with stable smokers and exsmokers with COPD $[105,113]$. This may be explained by a exaggerated neutrophilic inflammation, oxidant/antioxidant imbalance and microbial infection in more severe patients with COPD [114].

With exacerbations, the number of eosinophils, which are capable of expressing iNOS and producing NO [73, 115], may increase and this may also explain the further elevation of exhaled NO in patients with severe persistent asthma despite massive treatment with inhaled and/or oral steroids [19]. Eosinophils have been reported to be present in chronic bronchitis and COPD in particular during exacerbations, and exhaled NO correlated with the percentage of sputum eosinophils in COPD [116]. However, in contrast to asthma, the tissue eosinophils found in COPD do not degranulate and are not associated with increased expression of interleukin (IL)-5 [115, 117]. Therefore, mild elevation of exhaled NO in stable COPD might be a reflection of altered pulmonary mechanics and gas transfer, rather than airways inflammation. In fact, exhaled NO was significantly correlated with carbon monoxide diffusing capacity of the lungs (DL,CO) and was independent of inhaled corticosteroid therapy [118]. Acidosis is frequently associated with exacerbations of COPD and may have a direct vasodilatory influence on the systemic vasculature, and lead to increased NO production, and myeloperoxidase activity in lung [119]. In fact, in an acidic environment, the reaction between NO and oxygen radicals becomes further enhanced, leading to more tissue damage [120].

Two recently published articles on exhaled NO in COPD demonstrate largely opposing results which is most likely due to differences in methodology, patients selection and the heterogeneous disease entity such as COPD. Thus, elevated levels of exhaled NO were found in stable COPD (FEV1 43\% pred), compared with healthy control [107], whilst no difference in excretion rate of $\mathrm{NO}$ and nitrite/ nitrate in sputum supernatant was observed between 
nonatopic, steroid naive COPD patients (FEV1 63\% pred) compared also with healthy controls [116].

\section{Bronchiectasis}

The clinical relevance of exhaled NO measurements in bronchiectasis may be related to two issues. First, to identification of patients with infective exacerbations and therefore high levels of exhaled NO. Second, to separation of patients with $\mathrm{CF}$ and/or primary ciliary dyskinesia whose NO levels are abnormally low [121].

An increase in exhaled NO has been found in bronchiectasis and the level of NO was related to the extent of disease, as measured by a computerized tomography score [122]. Exhaled NO levels were not elevated compare to normal control in clinically stable patients with bronchiectasis [85]. It has been speculated that NO is either trapped in viscous airway secretions, or removed by reaction with reactive oxygen species, or epithelial iNOS has failed to be upregulated by chronic suppurative conditions.

\section{Primary ciliary dyskinesia}

Primary ciliary dyskinesia (PCD), a genetic disease characterized by defective motility of cilia, is another example where abnormally low nasal NO [121] might be useful in diagnosis. As NO plays an important role in bactericidal activity in the lungs [91, 92] and sodium and chloride transport in nasal epithelium [93], lack of endogenous NO production and defective nasal mucosa might account for the recurrent chest infections and male infertility in these patients. It has been shown that treatment with NO donor L-arginine [123] restored nasal NO and, therefore, improved mucociliary transport in PCD patients [121]. Therefore, measurements of nasal NO might be not only of diagnostic value in adults and children [124], but a major target and outcome in the treatment of patients with PCD.

\section{Interstitial lung diseases}

Clinical relevance of exhaled NO measurements in interstitial lung disease may be to help with the diagnosis of pulmonary hypertension and to identify patients with active inflammation.

The pathogenesis of pulmonary hypertension $(\mathrm{PH})$ remains poorly understood. Amongst vasoactive substances, vasoconstriction is likely to be a major factor in the disease, alteration of the NO has been cited as a possible pathogenic factor [125] but either reduction [27, 126, 127], or elevation [128-130], or variable [131], or unaltered [132] expression of endothelial NO-synthase (eNOS) have been reported in pulmonary vessels. Although, the levels of eNOS expression in small arterioles are significantly lower than in control subjects, consistently strong expression of eNOS is seen in the endothelium of plexiform lesions in both primary and secondary $\mathrm{PH}$ patients, suggesting that different therapeutic approaches might be applied [133]. Recently, no difference in nNOS1 in pulmonary arteries of patients with $\mathrm{PH}$ compare to control subjects has been reported, while abundant expression of endothelin-converting enzyme (ECE)-1, a potent vasoconstrictor, was present in diseased vessels [127].

In patients with $\mathrm{PH}$, secondary to systemic sclerosis, there is a reduction in exhaled NO compared to normal subjects and to patients with interstitial lung disease without PH $[125,134]$. This may be a reflection of the reduced eNOS expression described in patients with $\mathrm{PH}$ [27]. The reduced endogenous endothelial NO production as a result of chronic or acute pulmonary vascular endothelial injury in patients with $\mathrm{PH}$ or following cardiopulmonary bypass-operation [135] may aggravate pulmonary vasoconstriction and proliferation of vascular smooth muscle cells [13].

Elevated levels of exhaled NO in patients with fibrosing alveolitis were associated with disease activity as assessed by bronchioalveolar lavage (BAL) cell counts, and were reduced in patients treated with corticosteroids [136]. However, despite the absence of either exhaled NO or BAL, nitrite elevation in patients with active pulmonary sarcoidosis [137] there were significantly higher CO levels in exhaled breath of these patients (unpublished data). It may be possible, in the future, to monitor oxidative stress in pulmonary sarcoidosis more closely and to adjust treatment with the antioxidants which could be as effective as treatment with antioxidant N-Acetylcysteine in fibrosing alveolitis [138].

In patients with $\mathrm{PH}$, secondary to systemic sclerosis, there is a reduction in exhaled NO compared to normal subjects and to patients with interstitial lung disease without pulmonary hypertension $[125,134]$. This may be a reflection of the reduced endothelial NOS expression described in patients with PH [27]. The reduced endogenous endothelial NO production as a result of chronic or acute pulmonary vascular endothelial injury in patients with PH or following cardiopulmonary bypass-operation [135] may aggravate pulmonary vasoconstriction and proliferation of vascular smooth muscle cells [13].

Elevated levels of exhaled NO and CO in patients with fibrosing alveolitis were associated with disease activity as assessed by BAL cell counts [136]. However, despite the absence of either exhaled NO or BAL nitrite elevation in patients with active pulmonary sarcoidosis [137] there were significantly higher $\mathrm{CO}$ levels in exhaled breath of these patients (unpublished data). It may be possible, in the future, to monitor oxidative stress in pulmonary sarcoidosis more closely and to adjust treatment with the antioxidants, which could be as effective as treatment with antioxidant, N-Acetylcysteine in fibrosing alveolitis [138].

\section{Future directions}

There has been an interesting attempt to direct treatment with steroids in patients with moderate asthma according their levels of $\mathrm{PC}_{20}$ to methacholine [139]. Apart from small changes in PC20 (1.1 doubling dilution), because the majority of the patients had already been treated with inhaled steroids at baseline, the major limitation of this and others single-parameter-based-guidelines is its relatively weak link with airway inflammation. The advantage of exhaled NO is that it has a much stronger affiliation to airway inflammation, asthmatic/atopic inflammation in 
particular, and is much more sensitive to anti-inflammatory treatment so that the control of the disease can be improved without the risk of over-treatment.

Measurements of lipid mediators, such as cysteinylleukotrienes (LT) and other eicosanoids, in induced sputum [140] and exhaled condensate are promising approaches. However, the methodological issues, such as considerable within-subject variability of most sputum eicosanoid concentrations [140] needs to be addressed. Exhaled condensate, as it is less contaminated with saliva and proteines and is easy to collect in a controlled fashion, may have the advantages. Recently, significantly different levels of LT $\mathrm{E}_{4}, \mathrm{C}_{4}, \mathrm{D}_{4}, \mathrm{LTB}_{4}$ and nitrotyrosine in exhaled condensate of asthmatic patients of different severity before and after treatment with corticosteroids [141], and levels of IL-8 in $\mathrm{CF}$ patients during exacerbations, which were reduced after treatment with antibiotics (unpublished data).

Therefore, combination of exhaled NO measurements with determination of other inflammatory markers and mediators in exhaled breath condensate, such 8-isoprostane $[142,143]$, leukotrienes and prostaglandins, is a promising noninvasive approach towards asthma and COPD management.

Objective, noninvasive and effort independent monitoring of respiratory symptoms in adults and children with asthma is important for optimizing their anti-inflammatory treatment. Recently, a quantitative method has been used for tracking breath sounds overnight (PulmoTrack, Karmel, IL, USA) and during daytime in mild-to-severe asthma patients. The overnight wheeze scores were $>20$ times higher in moderate asthmatics on inhaled steroids compared with mild steroid naive asthma (unpublished data).

A combination of the cornerstone asthma sign such a wheeze, which is also related to airway obstruction, with a variety of inflammatory markers in exhaled breath and exhaled condensate may be clinically useful in detection and management of cytokine-mediated inflammatory lung disorders.

\section{References}

1. Hargreave FE, Leigh R. Induced sputum, eosinophilic bronchitis, and chronic obstructive pulmonary disease. Am J Respir Crit Care Med 1999; 160: S53-S57.

2. Nightingale JA, Rogers DF, Barnes PJ. Effect of repeated sputum induction on cell counts in normal volunteers. Thorax 1998; 53: 87-90.

3. Holz O, Richter K, Jorres RA, Speckin P, Mucke M, Magnussen $\mathrm{H}$. Changes in sputum composition between two inductions performed on consecutive days. Thorax 1998; 53: 83-86.

4. Kharitonov SA, Chung FK, Evans DJ, O'Connor BJ, Barnes PJ. The elevated level of exhaled nitric oxide in asthmatic patients is mainly derived from the lower respiratory tract. Am J Respir Crit Care Med 1996; 153: 1773-1780.

5. Saleh D, Ernst P, Lim S, Barnes PJ, Giaid A. Increased formation of the potent oxidant peroxynitrite in the airways of asthmatic patients is associated with induction of nitric oxide synthase: effect of inhaled glucocorticoid. FASEB J 1998; 12: 929-937.

6. Jatakanon A, Lim S, Kharitonov SA, Chung KF, Barnes PJ. Correlation between exhaled nitric oxide, sputum eosinophils, and methacholine responsiveness in patients with mild asthma. Thorax 1998; 53: 91-95.

7. Holz O, Weng B, Mucke M, et al. Detection of inducible NO-synthase (iNOS) in sputum cells of healthy and asthmatic subjects. Am J Respir Crit Care Med 1998; 157: A612.

8. Kips JC, Fahy JV, Hargreave FE, Ind PW. Methods for sputum induction and analysis of induced sputum: a method for assessing airway inflammation in asthma. Eur Respir J 1998; 11: Suppl. 26, 95-125.

9. Yates DH, Kharitonov SA, Barnes PJ. Effect of short- and long-acting inhaled $\beta_{2}$-agonists on exhaled nitric oxide in asthmatic patients. Eur Respir J 1997; 10: 1483-1488.

10. Baraldi E, Azzolin NM, Zanconato S, Dario C, Zacchello F. Corticosteroids decrease exhaled nitric oxide in children with acute asthma. J Pediatr 1997; 131: 381-385.

11. Fuglsang G, Vikre JJ, Agertoft L, Pedersen S. Effect of salmeterol treatment on nitric oxide level in exhaled air and dose-response to terbutaline in children with mild asthma. Pediatr Pulmonol 1998; 25: 314-321.

12. Hamid Q, Springall DR, Riveros-Moreno V, et al. Induction of nitric oxide synthase in asthma. Lancet 1993; 342: 1510-1513.

13. Barnes PJ, Liew FY. Nitric oxide and asthmatic inflammation. Immunol Today 1995; 16: 128-130.

14. Kharitonov SA, Yates DH, Robbins RA, Logan-Sinclair $\mathrm{R}$, Shinebourne EA, Barnes PJ. Increased nitric oxide in exhaled air of asthmatic patients. Lancet 1994; 343: $133-$ 135.

15. Marshall HE, Stamler JS. Exhaled nitric oxide (NO), NO synthase activity, and regulation of nuclear factor (NF)kappaB. Am J Respir Cell Mol Biol 1999; 21: 296-297.

16. Alving K, Weitzberg E, Lundberg JM. Increased amount of nitric oxide in exhaled air of asthmatics. Eur Respir $J$ 1993; 6: 1368-1370.

17. Kharitonov SA, Yates DH, Chung KF, Barnes PJ. Changes in the dose of inhaled steroid affect exhaled nitric oxide levels in asthmatic patients. Eur Respir J 1996; 9: 196-201.

18. Kharitonov SA, Yates DH, Barnes PJ. Inhaled glucocorticoids decrease nitric oxide in exhaled air of asthmatic patients. Am J Respir Crit Care Med 1996; 153: 454-457.

19. Stirling RG, Kharitonov SA, Campbell D, et al. Exhaled $\mathrm{NO}$ is elevated in difficult asthma and correlates with symptoms and disease severity despite treatment with oral and inhaled corticosteroids. Thorax 1998; 53: 10301034.

20. Lanz MJ, Leung DY, McCormick DR, Harbeck R, Szefler SJ, White CW. Comparison of exhaled nitric oxide, serum eosinophilic cationic protein, and soluble interleukin-2 receptor in exacerbations of pediatric asthma. Pediatr Pulmonol 1997; 24: 305-311.

21. Lanz MJ, Leung DY, White CW. Comparison of exhaled nitric oxide to spirometry during emergency treatment of asthma exacerbations with glucocorticosteroids in children. Ann Allergy Asthma Immunol 1999; 82: 161-164.

22. Leone AM, Gustafsson LE, Francis PL, Persson MG, Wiklund NP, Moncada S. Nitric oxide is present in exhaled breath in humans: direct GC-MS confirmation. Biochem Biophys Res Commun 1994; 201: 883-887.

23. Kharitonov SA, Alving K, Barnes PJ. Exhaled and nasal nitric oxide measurements: recommendations. Eur Respir $J$ 1997; 10: 1683-1693.

24. Anonymous. Recommendations for standardized procedures for the online and offline measurement of exhaled lower respiratory nitric oxide and nasal nitric oxide in 
adults and children. Am J Respir Crit Care Med 1999; 160: 2104-2117.

25. Palmer RM, Ferrige AG, Moncada S. Nitric oxide release accounts for the biological activity of endotheliumderived relaxing factor. Nature 1987; 327: 524-526.

26. Mason NA, Springall DR, Pomerance A, Evans TJ, Yacoub MH, Polak JM. Expression of inducible nitric oxide synthase and formation of peroxynitrite in posttransplant obliterative bronchiolitis. J Heart Lung Transplant 1998; 17: 710-714.

27. Giaid A, Saleh D. Reduced expression of endothelial nitric oxide synthase in the lungs of patients with pulmonary hypertension. N Engl J Med 1995; 333: 214-221.

28. McDermott CD, Gavita SM, Shennib H, Giaid A. Immunohistochemical localization of nitric oxide synthase and the oxidant peroxynitrite in lung transplant recipients with obliterative bronchiolitis. Transplantation 1997; 64: 270-274.

29. Massaro AF, Mehta S, Lilly CM, Kobzik L, Reilly JJ, Drazen JM. Elevated nitric oxide concentrations in isolated lower airway gas of asthmatic subjects. Am J Respir Crit Care Med 1996; 153: 1510-1514.

30. Lundberg JO, Weitzberg E, Nordvall SL, Kuylenstierna $\mathrm{R}$, Lundberg JM, Alving K. Primarily nasal origin of exhaled nitric oxide and absence in Kartagener's syndrome. Eur Respir J 1994; 7: 1501-1504.

31. Silkoff PE, McClean PA, Slutsky AS, et al. Marked flowdependence of exhaled nitric oxide using a new technique to exclude nasal nitric oxide. Am J Respir Crit Care Med 1997; 155: 260-267.

32. Gabbay E, Haydn WE, Orsida B, et al. In stable lung transplant recipients, exhaled nitric oxide levels positively correlate with airway neutrophilia and bronchial epithelial iNOS. Am J Respir Crit Care Med 1999; 160: 20932099.

33. Yates DH, Kharitonov SA, Robbins RA, Thomas PS, Barnes PJ. Effect of a nitric oxide synthase inhibitor and a glucocorticosteroid on exhaled nitric oxide. Am J Respir Crit Care Med 1995; 152: 892-896.

34. Yates DH, Kharitonov SA, Thomas PS, Barnes PJ. Endogenous nitric oxide is decreased in asthmatic patients by an inhibitor of inducible nitric oxide synthase. $\mathrm{Am} \mathrm{J}$ Respir Crit Care Med 1996; 154: 247-250.

35. Gomez FP, Barbera JA, Roca J, et al. Effect of nitric oxide synthesis inhibition with nebulized L-NAME on ventilation-perfusion distributions in bronchial asthma. Eur Respir J 1998; 12: 865-871.

36. Sartori C, Lepori M, Busch T, et al. Exhaled nitric oxide does not provide a marker of vascular endothelial function in healthy humans. Am J Respir Crit Care Med 1999; 160: 879-882.

37. Lim S, Jatakanon A, John M, Gilbey T, O'Connor BJ, Barnes PJ. Effect of inhaled budesonide on lung function and airway inflammation. Am J Respir Crit Care Med 1999; 159: 22-30.

38. Jatakanon A, Kharitonov SA, Lim S, Barnes PJ. Effect of differing doses of inhaled budesonide on markers of airway inflammation in patients with mild asthma. Thorax 1999; 54: 108-114.

39. Vathenen AS, Knox AJ, Wisniewski A, Tattersfield AE. Time course of change in bronchial reactivity with an inhaled corticosteroid in asthma. Am Rev Respir Dis 1991; 143: 1317-1321.

40. McFadden ER, Casale TB, Edwards TB, et al. Administration of budesonide once daily by means of turbuhaler to subjects with stable asthma. J Allergy Clin Immunol 1999; 104: 46-52.
41. Artlich A, Busch T, Lewandowski K, Jonas S, Gortner L, Falke KJ. Childhood asthma: exhaled nitric oxide in relation to clinical symptoms. Eur Respir J 1999; 13: 13961401.

42. Castagnaro A, Chetta A, Foresi A, D'Ippolito R, Malorgio $\mathrm{R}$, Olivieri D. Effect of sputum induction on spirometric measurements and arterial oxygen saturation in asthmatic patients, smokers, and healthy subjects. Chest 1999; 116: 941-945.

43. Holz O, Jorres RA, Koschyk S, Speckin P, Welker L, Magnussen H. Changes in sputum composition during sputum induction in healthy and asthmatic subjects. Clin Exp Allergy 1998; 28: 284-292.

44. Taylor DA, Jensen MW, Kanabar V, et al. A dosedependent effect of the novel inhaled corticosteroid ciclesonide on airway responsiveness to adenosine-5'monophosphate in asthmatic patients. Am J Respir Crit Care Med 1999; 160: 237-243.

45. Gershman NH, Liu H, Wong HH, Liu JT, Fahy JV. Fractional analysis of sequential induced sputum samples during sputum induction: evidence that different lung compartments are sampled at different time points. $J$ Allergy Clin Immunol 1999; 104: 322-328.

46. Jatakanon A, Uasuf CG, Maziak W, Lim S, Chung KF, Barnes PJ. Neutrophilic inflammation in severe persistent asthma. Am J Respir Crit Care Med 1999; 160: 15321539.

47. Tarodo dIF, Romagnoli M, Carlsson L, Godard P, Bousquet J, Chanez P. Eosinophilic inflammation assessed by induced sputum in corticosteroid-dependent asthma. Respir Med 1999; 93: 183-189.

48. Massaro AF, Gaston B, Kita D, Fanta C, Stamler JS, Drazen JM. Expired nitric oxide levels during treatment of acute asthma. Am J Respir Crit Care Med 1995; 152: 800-803.

49. Adisesh LA, Kharitonov SA, Yates DH, Snashal DC, Newman-Taylor AJ, Barnes PJ. Exhaled and nasal nitric oxide is increased in laboratory animal allergy. Clin Exp Allergy 1998; 28: 876-880.

50. Gratziou C, Dassiou M, Lignos M, Roussos C. Exhaled nitric oxide and bronchial hyperreactivity in atopic and non-atopic patients. Am J Respir Crit Care Med 1998; 157: A611.

51. Frank TL, Adisesh A, Pickering AC, et al. Relationship between exhaled nitric oxide and childhood asthma. Am J Respir Crit Care Med 1998; 158: 1032-1036.

52. Piacentini GL, Bodini A, Peroni DG, et al. Inhaled flunisolide can prevent an increase in exhaled nitric oxide levels in allergic asthmatic children exposed to relevant allergens. Eur Respir J 1998; 12: 142S.

53. Kharitonov SA, O'Connor BJ, Evans DJ, Barnes PJ. Allergen-induced late asthmatic reactions are associated with elevation of exhaled nitric oxide. Am J Respir Crit Care Med 1995; 151: 1894-1899.

54. Baraldi E, Carra S, Dario C, et al. Effect of natural grass pollen exposure on exhaled nitric oxide in asthmatic children. Am J Respir Crit Care Med 1999; 159: 262-266.

55. Simpson A, Custovic A, Pipis S, Adisesh A, Faragher B, Woodcock A. Exhaled nitric oxide, sensitization, and exposure to allergens in patients with asthma who are not taking inhaled steroids. Am J Respir Crit Care Med 1999; 160: 45-49.

56. Henriksen AH, Sue-Chu M, Lingaas Holmen T, Langhammer A, Bjermer L. Exhaled and nasal NO levels in allergic rhinitis: relation to sensitization, pollen season, and bronchial hyperresponsiveness. Eur Respir $J$ 1999; 13: 301-306. 
57. Piacentini GL, Bodini A, Costella S, et al. Allergen avoidance is associated with a fall in exhaled nitric oxide in asthmatic children. $J$ Allergy Clin Immunol 1999; 104: 1323-1324.

58. Gratziou C, Lignos M, Dasiou M, Alexandri A, Katsardis $\mathrm{Ch}$, Roussos C. The influence of atopy on exhaled nitric oxide in patients with asthma and/or rhinitis. Eur Respir $J$ 1998; 12: $127 \mathrm{~S}$

59. Gratziou C, Lignos M, Dasiou M, Katsardis Ch, Roussos C. Exhaled nitric oxide, bronchial hyperreactivity and airways obstruction in asthmatics and nonasthmatics subjects. Eur Respir J 1998; Suppl. 28, 12: 364S.

60. Ho LP, Wood F, Robson A, Innes JA, Greening AP. Exhaled nitric oxide in asthmatics correlates with atopy and bronchial reactivity but not with steroids use or clinical control. Am J Respir Crit Care Med 1998; 157: A608.

61. Simpson A, Custovic A, Adisesh A, Pipis S, Woodcock A. Sensitization, and exposure to allergens in patients with asthma who are not taking inhaled steroids. $\mathrm{Am} \mathrm{J}$ Respir Crit Care Med 1998; 160: 45-49.

62. Silvestri M, Spallarossa D, Yourukova VF, Battistini E, Fregonese B, Rossi GA. Orally exhaled nitric oxide levels are related to the degree of blood eosinophilia in atopic children with mild-intermitten asthma. Eur Respir J 1999; 13: 321-326.

63. Chatkin JM, Ansarin K, Silkoff PE, et al. Exhaled nitric oxide as a noninvasive assessment of chronic cough. Am J Respir Crit Care Med 1999; 159: 1810-1813.

64. Dupont LJ, Rochette F, Demedts MG, Verleden GM. Exhaled nitric oxide correlates with airway hyperresponsiveness in steroid-naive patients with mild asthma. Am J Respir Crit Care Med 1998; 157: 894-898.

65. Parameswaran K, Kamada D, Borm A, et al. Sputum cell counts and exhaled nitric oxide in patients with nonasthmatic cough and gastro-esophageal reflux. Eur Respir $J$ 1998; Suppl. 28, 12: 248S

66. Massaro AF, Gaston B, Kita D, Fanta C, Stamler JS, Drazen JM. Expired nitric oxide levels during treatment of acute asthma. Am J Respir Crit Care Med 1995; 152: 800-803.

67. Baraldi E, Dario C, Ongaro R, et al. Exhaled nitric oxide concentrations during treatment of wheezing exacerbation in infants and young children. Am J Respir Crit Care Med 1999; 159: 1284-1288.

68. Jatakanon A, Lim A, Chung KF, Barnes PJ. An inhaled steroid improves markers of airway inflammation in patients with mild asthma. Eur Respir J 1998; 12: 10841088.

69. van RE, Straathof KC, Veselic-charvat MA, Zwinderman AH, Bel EH, Sterk PJ. Effect of inhaled steroids on airway hyperresponsiveness, sputum eosinophils, and exhaled nitric oxide levels in patients with asthma. Thorax 1999; 54: 403-408.

70. Sato K, Sumino H, Sakamaki T, et al. Lack of inhibitory effect of dexamethasone on exhalation of nitric oxide by healthy humans. Intern Med 1996; 35: 356-361.

71. Borish LC, Nelson HS, Lanz MJ, et al. Interleukin-4 receptor in moderate atopic asthma. A phase $\mathrm{i} / \mathrm{ii}$ randomized, placebo-controlled trial. Am J Respir Crit Care Med 1999; 160: 1816-1823.

72. Kharitonov SA, Barnes PJ, O'Connor BJ. Reduction in exhaled nitric oxide after a single dose of nebulized budesonide in patients with asthma. Am J Respir Crit Care Med 1996; 153: A799.

73. Silkoff PE, McClean PA, Slutsky AS, et al. Exhaled nitric oxide and bronchial reactivity during and after inhaled beclomethasone in mild asthma. $J$ Asthma 1998 ; 35: 473479.

74. Kharitonov SA, Donnelly LE, Corradi M, Montuschi P, Barnes PJ. Dose-dependent onset and duration of action of 100/400 mcg budesonide on exhaled nitric oxide and related changes in other potential markers of airway inflammation in mild asthma. Am J Respir Crit Care Med 2000; 161: A186.

75. Gribbe O, Lundeberg T, Samuelson UE, Wiklund NP. Dexamethasone increases survival and attenuates induction of inducible nitric oxide synthase in experimental skin flaps. Ann Plast Surg 1999; 42: 180-184.

76. del Pozo V, de-Arruda CE, de AB, et al. Eosinophils transcribe and translate messenger RNA for inducible nitric oxide synthase. J Immunol 1997; 158: 859-864.

77. Tomita K, Chikumi H, Tokuyasu H, et al. Functional assay of NF-kappaB translocation into nuclei by laser scanning cytometry: inhibitory effect by dexamethasone or theophylline. Naunyn Schmiedebergs Arch Pharmacol 1999; 359: 249-255.

78. Garnier P, Fajac I, Dessanges JF, Dall'ava-Santucci J, Lockhart A, Dinh-Xuan AT. Exhaled nitric oxide during acute changes of airways calibre in asthma. Eur Respir $J$ 1996; 9: 1134-1138.

79. Kobayashi H, Takahashi Y, Mitsufuji H, et al. Decreased exhaled nitric oxide in mild persistent asthma patients treated with a leukotriene receptor antagonist, pranlukast. Jpn J Physiol 1999; 49: 541-544.

80. Bisgaard H, Loland L, Oj JA. NO in exhaled air of asthmatic children is reduced by the leukotriene receptor antagonist montelukast. Am J Respir Crit Care Med 1999; 160: $1227-1231$.

81. Bratton DL, Lanz MJ, Miyazawa N, White CW, Silkoff PE. Exhaled nitric oxide before and after montelukast sodium therapy in school-age children with chronic asthma: a preliminary study. Pediatr Pulmonol 1999; 28: 402-407.

82. Kharitonov SA, Sapienza MA, Barnes PJ, Chung KF. Prostaglandins $E_{2}$ and $F_{2 \alpha}$ reduce exhaled nitric oxide in normal and asthmatic subjects irrespective of airway calibre changes. Am J Respir Crit Care Med 1998; 158: 1374-1378.

83. Kharitonov SA, Sapienza MM, Chung KF, Barnes PJ. Prostaglandins mediate bradykinin-induced reduction of exhaled nitric oxide in asthma. Eur Respir J 1999; 14: $1023-1027$.

84. Aizawa $\mathrm{H}$, Inoue $\mathrm{H}$, Nakano $\mathrm{H}$, et al. Effects of thromboxane $\mathrm{A}_{2}$ antagonist on airway hyperresponsiveness, exhaled nitric oxide, and induced sputum eosinophils in asthmatics. Prostaglandins Leukot Essent Fatty Acids 1998; 59: 185-190.

85. Ho LP, Innes JA, Greening AP. Exhaled nitric oxide is not elevated in the inflammatory airways diseases of cystic fibrosis and bronchiectasis. Eur Respir J 1998; 12: 12901294.

86. Lundberg JON, Nordvall SL, Weitzberg E, Kollberg H, Alving K. Exhaled NO in pediatric asthma and cystic fibrosis. Arch Dis Childhood 1996; 75: 323-326.

87. Grasemann H, Michler E, Wallot M, Ratjen F. Decreased concentration of exhaled nitric oxide (NO) in patients with cystic fibrosis. Pediatr Pulmonol 1997; 24: 173177.

88. Dotsch J, Demirakca S, Terbrack HG, Huls G, Rascher W, Kuhl PG. Airway nitric oxide in asthmatic children and patients with cystic fibrosis. Eur Respir J 1996; 9: 25372540 .

89. Lundberg JO, Nordvall SL, Weitzberg E, Kollberg H, 
Alving K. Exhaled nitric oxide in paediatric asthma and cystic fibrosis. Arch Dis Child 1996; 75: 323-326.

90. Balfour-Lynn IM, Laverty A, Dinwiddie R. Reduced upper airway nitric oxide in cystic fibrosis. Arch Dis Child 1996; 75: 319-322.

91. Kelley TJ, Drumm ML. Inducible nitric oxide synthase expression is reduced in cystic fibrosis murine and human airway epithelial cells. J Clin Invest 1998; 102: 1200 1207.

92. Meng QH, Springall DR, Bishop AE, et al. Lack of inducible nitric oxide synthase in bronchial epithelium: a possible mechanism of susceptibility to infection in cystic fibrosis. J Pathol 1998; 184: 323-331.

93. Elmer HL, Brady KG, Drumm ML, Kelley TJ. Nitric oxide-mediated regulation of transepithelial sodium and chloride transport in murine nasal epithelium. $\mathrm{Am} \mathrm{J}$ Physiol 1999; 276: L466-L473.

94. Armstrong DS, Grimwood K, Carlin JB, et al. Lower airway inflammation in infants and young children with cystic fibrosis. Am J Respir Crit Care Med 1997; 156: 1197-1204.

95. Hull J, Vervaart P, Grimwood K, Phelan P. Pulmonary oxidative stress response in young children with cystic fibrosis. Thorax 1997; 52: 557-560.

96. Jones KL, Bryan TW, Jinkins PA, et al. Superoxide causes a reduction in nitric oxide gas and an increase in nitrate. Am J Physiol 1998; 275: L1120-L1126.

97. Witko SV, Delacourt C, Rabier D, Bardet J, Nguyen AT, Descamps LB. Neutrophil-derived long-lived oxidants in cystic fibrosis sputum. Am J Respir Crit Care Med 1995; 152: 1910-1916.

98. Linnane SJ, Keatings VM, Costello CM, et al. Total sputum nitrate plus nitrite is raised during acute pulmonary infection in cystic fibrosis. Am J Respir Crit Care Med 1998; 158: 207-212.

99. Brown RK, Kelly FJ. Evidence for increased oxidative damage in patients with cystic fibrosis. Pediatr Res 1994; 36: 487-493.

100. Brown RK, Wyatt H, Price JF, Kelly FJ. Pulmonary dysfunction in cystic fibrosis is associated with oxidative stress. Eur Respir J 1996; 9: 334-339.

101. Brown RK, McBurney A, Lunec J, Kelly FJ. Oxidative damage to DNA in patients with cystic fibrosis. Free Radic Biol Med 1995; 18: 801-806.

102. Robbins RA, Floreani AA, Von Essen SG, et al. Measurement of exhaled nitric oxide by three different techniques. Am J Respir Crit Care Med 1996; 153: 16311635.

103. Roger N, Barbera JA, Roca J, Rovira I, Gomez FP, Rodriguez RR. Nitric oxide inhalation during exercise in chronic obstructive pulmonary disease. Am J Respir Crit Care Med 1997; 156: 800-806.

104. Kanazawa H, Shoji S, Hirata K, Kurthara N, Yoshikawa J. Role of endogenous nitric oxide in airflow obstruction in smokers. Chest 1996; 110: 927-929.

105. Bellofiore S, Sapienza MA, Patanè A, Mistretta A, Di Maria GU. Increased levels of exhaled nitric oxide in smoking subjects with stable chronic obstructive pulmonary disease and in patients with COPD exacerbation. Eur Respir J 1998; 12: 430S

106. Kharitonov SA, Robbins RA, Yates DH, Keatings V, Barnes PJ. Acute and chronic effects of cigarette smoking on exhaled nitric oxide. Am J Respir Crit Care Med 1995; 152: 609-612.

107. Corradi M, Majori M, Cacciani G, Consugli GF, De'Munari E, Pesci A. Increased nitric oxide in exhaled air of patients with stable chronic obstructive pulmonary disease. Eur Respir J 1999; 54: 572-575.

108. Olin AC, Hellgren J, Karlsson G, Ljungkvist G, Nolkrantz K, Toren K. Nasal nitric oxide and its relationship to nasal symptoms, smoking and nasal nitrate. Rhinol 1998; 36: 117-121.

109. Su Y, Han W, Giraldo C, De Li Y, Block ER. Effect of cigarette smoke extract on nitric oxide synthase in pulmonary artery endothelial cells. Am J Respir Cell Mol Biol 1998; 19: 819-825.

110. Robbins RA, Millatmal T, Lassi K, Rennard S, Daughton D. Smoking cessation is associated with an increase in exhaled nitric oxide. Chest 1997; 112: 313-318.

111. Petruzzelli S, Puntoni R, Mimotti P, et al. Plasma 3nitrotyrosine in cigarette smokers. Am J Respir Crit Care Med 1997; 156: 1902-1907.

112. Yermilov V, Rubio J, Ohshima H. Formation of 8nitroguanine in DNA treated with peroxynitrite in vitro and its rapid removal from DNA by depurination. FEBS Lett 1995; 376: 207-210.

113. Maziak W, Loukides S, Culpitt S, Sullivan P, Kharitonov SA, Barnes PJ. Exhaled nitric oxide in chronic obstructive pulmonary disease. Am J Respir Crit Care Med 1998; 157: 998-1002.

114. Keatings VM, Collins PD, Scott DM, Barnes PJ. Differences in interleukin-8 and tumor necrosis factor-alpha in induced sputum from patients with chronic obstructive pulmonary disease or asthma. Am J Respir Crit Care Med 1996; 153: 530-534.

115. Jeffery PK. Structural and inflammatory changes in COPD: a comparison with asthma. Thorax 1998; 53: 129-136.

116. Rutgers SR, van der Mark TW, Coers W, et al. Markers of nitric oxide metabolism in sputum and exhaled air are not increased in chronic obstructive pulmonary disease. Thorax 1999; 54: 576-580.

117. Saetta M, Turato G, Corbino L, et al. Mechanisms of damage in COPD. Mon Arch Chest Dis 1997; 52: 6-568.

118. Ansarin K, Chatkin JM, Ghiculete D, Zamel N, Chapman KR. Exhaled nitric oxide levels in patients with chronic obstructive pulmonary disease. Eur Respir $J$ 1998; 12: Suppl. 28, 432s.

119. Pedoto A, Caruso JE, Nandi J, et al. Acidosis stimulates nitric oxide production and lung damage in rats. $A m J$ Respir Crit Care Med 1999; 159: 397-402.

120. Prior WA, Squadrito GL. The chemistry of peroxymitrite: a product from the reaction of nitric oxide with superoxide. Am J Physiol 1995; 268: L699-L722.

121. Loukides S, Kharitonov SA, Wodehouse T, Cole PJ, Barnes PJ. Effect of L-arginine on mucociliary function in primary ciliary dyskinesia. Lancet 1998; 352: 371-372.

122. Kharitonov SA, Wells AU, O'Connor BJ, et al. Elevated levels of exhaled nitric oxide in bronchiectasis. $\mathrm{Am} \mathrm{J}$ Respir Crit Care Med 1995; 151: 1889-1893.

123. Kharitonov SA, Lubec G, Lubec B, Hjelm M, Barnes PJ. $\mathrm{L}$-arginine increases exhaled nitric oxide in normal human subjects. Clin Sci 1995; 88: 135-139.

124. Narang I, Wilson NW, Ersu R, Bush A. The use of exhaled nitric oxide levels as a screening tool in respiratory disease states. Am J Respir Crit Care Med 2000; 161 : A223.

125. Kharitonov SA, Cailes JB, Black CM, Du Bois RM, Barnes PJ. Decreased nitric oxide in the exhaled air of systemic sclerosis patients with pulmonary hypertension. Thorax 1997; 52: 1051-1055.

126. Hislop AA, Springall DR, Oliveira H, Pollock JS, Polak JM, Haworth SG. Endothelial nitric oxide synthase in 
hypoxic newborn porcine pulmonary vessels. Arch Dis Child Fetal Neonatal Ed 1997; 77: F16-F22.

127. Giaid A. Nitric oxide and endothelin-1 in pulmonary hypertension. Chest 1998; 114: 208S-212S.

128. Hampl V, Archer SL, Nelson DP, Weir EK. Chronic EDRF inhibition and hypoxia: effects on pulmonary circulation and systemic blood pressure. J Appl Physiol 1993; 75: 1748-1757.

129. Xue C, Johns RA. Endothelial nitric oxide synthase in the lungs of patients with pulmonary hypertension. $N$ Engl $J$ Med 1995; 333: 1642-1644.

130. Black SM, Fineman JR, Steinhorn RH, Bristow J, Soifer SJ. Increased endothelial NOS in lambs with increased pulmonary blood flow and pulmonary hypertension. $\mathrm{Am} \mathrm{J}$ Physiol 1998; 275: H1643-H1651.

131. Tyler RC, Muramatsu M, Abman SH, et al. Variable expression of endothelial NO synthase in three forms of rat pulmonary hypertension. Am J Physiol 1999; 276: L297-L303.

132. Everett AD, Le CT, Xue C, Johns RA. eNOS expression is not altered in pulmonary vascular remodeling due to increased pulmonary blood flow. Am J Physiol 1998; 274: L1058-L1065.

133. Mason NA, Springall DR, Burke M, et al. High expression of endothelial nitric oxide synthase in plexiform lesions of pulmonary hypertension. J Pathol 1998; 185: 313-318.

134. Riley MS, Porszasz J, Miranda J, Engelen MP, Brundage $\mathrm{B}$, Wasserman K. Exhaled nitric oxide during exercise in primary pulmonary hypertension and pulmonary fibrosis. Chest 1997; 111: 44-50.

135. Beghetti M, Silkoff PE, Caramori M, Holtby HM, Slutsky AS, Adatia I. Decreased exhaled nitric oxide may be a marker of cardiopulmonary bypass-induced injury. Ann Thorac Surg 1998; 66: 532-534.

136. Paredi P, Kharitonov SA, Loukides S, Pantelidis P, Du
Bois RM, Barnes PJ. Exhaled nitric oxide is increased in active fibrosing alveolitis. Chest 1999; 115: 1352-1356.

137. O'Donnell DM, Moynihan J, Finlay GA, et al. Exhaled nitric oxide and bronchoalveolar lavage nitrite/nitrate in active pulmonary sarcoidosis. Am J Respir Crit Care Med 1997; 156: 1892-1896.

138. Behr J, Maier K, Degenkolb B, Krombach F, Vogelmeier C. Antioxidative and clinical effects of high-dose Nacetylcysteine in fibrosing alveolitis. Adjunctive therapy to maintenance immunosuppression. Am J Respir Crit Care Med 1997; 156: 1897-1901.

139. Sont JK, Willems LN, Bel EH, van Krieken JH, Vandenbroucke JP, Sterk PJ. Clinical control and histopathologic outcome of asthma when using airway hyperresponsiveness as an additional guide to long-term treatment. The AMPUL Study Group. Am J Respir Crit Care Med 1999; 159: 1043-1051.

140. Pavord ID, Ward R, Woltmann G, Wardlaw AJ, Sheller JR, Dworski R. Induced sputum eicosanoid concentrations in asthma. Am J Respir Crit Care Med 1999; 160: 1905-1909.

141. Hanazawa T, Kharitonov SA, Oldfield W, Kay AB, Barnes PJ. Nitrotyrosine and cystenyl leukotrienes in breath condensates are increased after withdrawal of steroid treatment in patients with asthma. Am J Respir Crit Care Med 2000; 161: A919.

142. Montuschi P, Corradi M, Ciabattoni G, Nightingale J, Kharitonov SA, Barnes PJ. Increased 8-isoprostane, a marker of oxidative stress, in exhaled condensate of asthma patients. Am J Respir Crit Care Med 1999; 160: 216-220.

143. Montuschi P, Corradi M, Ciabattoni G, et al. Breath condensate analysis of 8-isoprostane: a new approach for assessment of oxidative stress in patients with chronic obstructive pulmonary disease. Am J Respir Crit Care Med 1999; 159: A798. 